\title{
Literature of the Crusades, edited by Simon Thomas PARSONS, Linda M. PATERSON
}

\section{G. Matteo Roccati}

\section{OpenEdition}

\section{Journals}

\section{Édition électronique}

URL : http://journals.openedition.org/studifrancesi/16152

DOI : $10.4000 /$ studifrancesi. 16152

ISSN : 2427-5856

\section{Éditeur}

Rosenberg \& Sellier

\section{Édition imprimée}

Date de publication : 1 juillet 2019

Pagination : 132-133

ISSN : 0039-2944

\section{Référence électronique}

G. Matteo Roccati, «Literature of the Crusades, edited by Simon Thomas PARSONs, Linda M. PATERSON », Studi Francesi [En ligne], 187 (LXIII | I) | 2019, mis en ligne le 01 juillet 2019, consulté le 25 janvier 2021. URL : http://journals.openedition.org/studifrancesi/16152; DOI : https://doi.org/10.4000/ studifrancesi. 16152

Ce document a été généré automatiquement le 25 janvier 2021.

\section{(c) (i) (9)}

Studi Francesi è distribuita con Licenza Creative Commons Attribuzione - Non commerciale - Non opere derivate 4.0 Internazionale. 


\title{
Literature of the Crusades, edited by Simon Thomas PARSONS, Linda M.
}

\section{PATERSON}

\author{
G. Matteo Roccati
}

\section{RÉFÉRENCE}

Literature of the Crusades, edited by Simon Thomas PARSONS, Linda M. PATERSON, Cambridge, D.S. Brewer, 2018, pp. xIV-210.

1 L'Introduction, par Ruth HARVEY et Simon Thomas PARSONS, pp. 1-6, présente les dix contributions rassemblées dans le volume, toutes traitant des «literary responses to the crusading movement within Europe, in both Latin and the vernacular» (p. 2). Simon JOHN, 'Claruit Ibi Multum Dux Lotharingiae'. The Development of the Epic Tradition of Godfrey of Bouillon and the Bisected Muslim, pp. 7-24, suit, à travers neuf versions du XII ${ }^{\mathrm{e}}$ siècle, l'élaboration progressive de l'épisode du guerrier musulman coupé en deux verticalement d'un seul coup d'épée par Godefroi de Bouillon le 6 mars 1098 lors du siège d'Antioche, exemple de "micronarrative" de caractère épique à la croisée de l'oralité et de l'historiographie écrite de la croisade. Carol SWEETENHAM, Reflecting and Refracting Reality. The Use of Poetic Sources in Latin Accounts of the First Crusade, pp. 25-40, enquête sur les sources poétiques vernaculaires (chansons de geste, lais et octosyllabes narratifs, hagiographie, lyrique) dans les chroniques latines en prose relatives à la première croisade. Stephen J. SPENCER, Emotions and the 'Other'. Emotional Characterizations of Muslim Protagonists in Narratives of the Crusades (1095-1192), pp. 41-54, montre que les «emotional descriptors participated in, and helped to reinforce, [the] fundamental binary opposition within Latin crusade chronicles» (p. 42) entre chrétiens et musulmans. Simon Thomas PARSONS, A Unique Song of the First Crusade? New Observations on the Hatton 77 Manuscript of the «Siège d'Antioche», pp. 55-74, examine le texte contenu dans les ms. Oxford, Bodl. Libr., Hatton 77, intéressant en tant que témoin des 
matériaux circulant oralement à la base des récits latins relatifs à la Première Croisade; il conclut «there is some indication that it preserves information on a particularly Norman/Angevin/Percheron group of participants» (p. 74). Luca BARBIERI, Crusade Songs and the old French Literary Canon, pp. 75-95, traduction d'un article paru dans «Medioevi» (2015). Miriam CABRÉ, Wielding the Cross. Crusade References in Cerverí de Girona and Thirteenth-Century Catalan Historiography, pp. 96-108, traite de la thématique de la croisade comme instrument de propagande dans l'historiographie catalane et dans les lyriques de Cerverí de Girona. Anna RADAELLI, 'Voil ma chançun a la gent fere oïr'. An AngloNorman Crusade Appeal (London, BL Harley 1717, fol. 251v), pp. 109-133, traduction d'un article paru dans «Cultura Neolatina» (2013). Charmaine LEE, Richard the Lionheart. The Background to 'Ja nus homs pris', pp. 134-149, explicite les références au contexte historique et s'en sert pour l'établissement du texte. Jean DunBABIN, Charles of Anjou. Crusaders and Poets, pp. 150-157, passe en revue les œuvres écrites en soutien de Charles d'Anjou (Rutebeuf) et les passages dans les textes littéraires (parmi lesquels Le garçon et l'aveugle, Jean de Meung) où l'on entend l'écho de la propagande en faveur de la conquête du royaume de Sicile en 1266, justifiée comme une croisade. Helen J. NICHOLSON, Remembering the Crusaders in Cyprus. The Lusignans, the Hospitallers and the 1191 Conquest of Cyprus in Jean d'Arras's «Mélusine», pp. 158-172, traite de la réélaboration de l'histoire de Chypre par Jean d'Arras et met en lumière son enracinement dans le contexte de la fin du XIV e siècle: le roman est reçu comme un appel à la croisade et une justification des prétentions françaises sur l'ile. 